\title{
Decentralized oceans: Sail-solar shipping for sustainable development in SIDS
}

$\operatorname{AUTHOR}(S)$ :

Teeter, Jennifer Louise; Cleary, Steven A.

\section{CITATION:}

Teeter, Jennifer Louise ...[et al]. Decentralized oceans: Sail-solar shipping for sustainable development in SIDS. Natural Resources Forum 2014, 38(3): 182-192

\section{ISSUE DATE:}

2014-08-22

URL:

http://hdl.handle.net/2433/194152

\section{RIGHT:}

This is the accepted version of the following article: Teeter Jennifer Louise, Cleary Steven A. Decentralized oceans: Sailsolar shipping for sustainable development in SIDS

Natural Resources Forum. 38(3) 182-192. 2014. which has been published in final form at

http://dx.doi.org/10.1111/1477-8947.; 許諾条件により、本文は2016-08-22に公開.; This is not the published version. Please cite only the published version:; この論文は出版社版でありません。引用の際には出版社版をご確認ご利用くだ さい。 


\title{
Decentralized oceans: Sail-solar shipping for sustainable development in SIDS
}

\author{
Jennifer Louise Teeter and Steven A. Cleary
}

\begin{abstract}
Conventional shipping is increasingly unable to address the social and economic needs of remote and underprivileged coastal and island communities. Barriers include rising fuel costs affecting the viability of on-water activities, which are compounded by the challenges presented by a lack of deepwater ports and related infrastructure that prevent docking by larger more fuel-efficient vessels. The environmental externalities of shipping-related fossil-fuel consumption, which harbour both local pollution and anthropogenic climate change impacts, adversely affect these communities. Amid limited research on strategies to address the challenges presented by conventional shipping methods to small island developing States (SIDS), this paper proposes the adoption of policy initiatives for the adoption of small, modern non-fuel vessels that could assist these important yet underserved niches. One of several initiatives developing renewable-energy based shipping solutions is the Greenheart Project, an international non-profit organization in the process of developing an open-source hybrid solar-sail cargo vessel conforming to the conditions faced in coastal and island communities. This paper discusses the socio-economic and environmental challenges presented by conventional shipping with reference to SIDS and the potential of non-fuel shipping. Policy proposals to facilitate the beneficial adoption of such vessels in developing communities will also be offered.
\end{abstract}

Keywords: Sustainable development; renewable energy-based shipping; sail-solar vessels; SIDS; oceans.

\section{Introduction}

Whereas the rise of globalization has resulted in growth in trade flows, not all are well placed to share in the benefits. Massive conventional fossil-fueled cargo vessels are the workhorses of the globalized economy, transporting goods and seafood to distant ports, yet the bounty they carry is not easily accessible to all coastal and island communities (CICs). Furthermore, those on the margins of the global shipping network, due to lack of capital, undeveloped markets, low relative purchasing power and absence of deepwater ports are at risk of becoming further marginalized.

With the cost of fuel oils increasing, keeping smaller vessels in the water to provide basic transportation and other services that are the lifeblood of the coasts is increasingly cost prohibitive especially for remote coastal communities and small island developing states (SIDS), Reduced services result in social, environmental, and economic impacts at local and regional levels. Proximate

Jennifer Louise Teeter is at Kyoto University, Kyoto, Japan, and a volunteer for the Greenheart Project. E-mail: teeter42@gmail.com

Steven Cleary is a volunteer for the Greenheart Project. E-mail: steven.a.cleary@gmail.com

(c) 2014 The Authors. Natural Resources Forum (c) 2014 United Nations deep-sea fisheries (many of which are located in the global commons) can be out of reach of CICs due to combinations of fuel cost, range and market access. For less privileged CICs, the seas, having at times represented freedom and opportunity, are increasingly becoming a barrier that can exacerbate isolation and poverty as well as hinder development.

Acknowledging the restraints imposed by dependence on imported fossil fuels, Governments of Pacific island State have been placing a priority on moving towards renewable energy sources. However, discussions on ways to eliminate the requirement for fossil fuel use in shipping remain few and far between (Woodruff, 2007; Holland et al., 2014). This absence is in contrast to the increasing availability and continued emergence of renewable energy solutions for marine and riverine transport (Nuttall, 2012; Nuttall et al., 2013; Prasad et al., 2013; Rojon, 2013).

The Greenheart Project is one of several initiatives attempting to address these issues. It is doing so through the development and promotion of a design of small non-fuel ships propelled by wind and powered by sun. This paper will examine the feasibility of Greenheart-class vessels in providing a reliable alternative to fossil fueled shipping for CICs, while also providing a multi-functional vessel 
with the flexibility to be used beyond just fishing or transportation of cargo.

This paper seeks to identify the socio-economic and environmental challenges presented by conventional shipping methods to SIDS, before discussing the potential of non-fuel shipping in the form of Greenheart-class vessels to address the same. It will then offer some policy proposals that could facilitate the beneficial adoption of such vessels in developing communities.

\section{Shipping, sustainability, sailing and SIDS}

\subsection{SIDS}

For the purposes of this study as outlined above, the terms "SIDS" and "marginalized" are used. "SIDS" is used here as the term best able to identify common characteristics that an island State shares with others, including but not limited to small size, remoteness, vulnerability to external shock, a narrow resources base, and exposure to global environmental issues (see United Nations, 2010). ${ }^{1}$ The UN ascribes the label SIDS to 32 island States in the Caribbean, the Pacific, Africa, the Indian Ocean and the South China Sea, with a combined population reaching 63.2 million people (United Nations, 2014b).

The Commonwealth of Nations and UNESCO began laying the groundwork for the conceptual framing of SIDS in the 1970s, leading to recognition as an official group at the 1992 UN Conference on Environment and Development (Crossley and Sprague, 2014). Since then, work confronting the unique challenges of SIDS has led to the proclamation of 2014 as the UN International Year of the Small Island Developing State, in order to celebrate their diversity and contributions to the world as well as to raise awareness of their "ingenuity, innovation and use of traditional knowledge" in confronting local and global challenges (United Nations, 2014a:5).

An increasing mismatch between the social and economic needs of SIDS and the ability of conventional shipping to respond is becoming evident. At the same time conventional shipping is increasingly raising issues of environmental sustainability.

\subsection{Nexus of shipping and poverty, unemployment, and urban drift in SIDS}

The seas connecting island and coastal regions that were once filled with fleets of small vessels are increasingly

\footnotetext{
${ }^{1}$ By using the term "SIDS", it is not the authors' intention to downplay the diversity found in the number of countries that fall under these labels in categories based solely on income, distributions of standards of living, or other indicators. Furthermore, the term "marginalized" will be used in reference to those people or communities excluded from participation in long-distance commercial shipping because of rising cost thresholds.
}

empty (Young, 1993). The high cost of fuel forces merging and reduction of basic mail, cargo, and ferry routes to areas with small populations, making living in such places inconvenient even in relatively wealthy countries (World Bank, 2004).

In SIDS, such as Indonesia and Fiji, transport services to smaller islands can be reduced to as few as once a week, or even once a month (Rutz and Coull, 1996). At the same time, transport between neighbouring Pacific countries can even involve routing through New Zealand - a detour of vastly inefficient proportions. Furthermore, investment in a vessel sometimes does not provide positive return on investment, due to difficulties in gaining access to costly or difficult-to-find replacement parts or changes in viability in the face of rising costs consigning such ships to rust (Al Jazeera, 2013).

Accessibility has become a principal issue; communities that were once connected by the water, are now increasingly separated by it. Access can be understood as the level of ease, efficiency, and cost at which people/services can be connected to other locations via roads, rail, sail, or harbours through a variety of services (Teeter, 2014). The Liner Shipping Connectivity Index measures countries' levels of integration into liner shipping networks through various components: the number of ships, the total containercarrying capacity of such ships, the maximum vessel size, the number of services, and the number of companies that deploy container ships on services from and to a country's ports (UNCTAD, 2013). Comparing the connectivity of high gross national income (GNI) countries with SIDS, the difference becomes apparent, with an average score of 9 compared to an average score of 51 for the top GNI countries on a scale of 1.59 (Dominica) to 106.9 (Singapore) (Teeter, 2014).

Due to these barriers and gaps in accessibility in regions including the Pacific and Caribbean, basic services (education, health, even mail delivery) have become increasingly difficult to provide, in large part due to the cost, inaccessibility and difficulty of transportation. Whereas urban drift is often motivated by economic reasons, technological and institutional changes have been associated with urban drift, as seen in sub-Saharan Africa (Fox, 2012). Job opportunities are also extremely limited, with many islands locked into subsistence farming and fishing. Even when residents produce a surplus to sell, accessing markets for that produce can be prohibitively difficult.

Many residents tend to feel isolated and trapped in poverty, strengthening the pressure to emigrate to urban areas, or even abroad (Russell, 2009). Unfortunately, regional cities are ill equipped to handle the large influxes (of often unskilled labour), and rapid urbanization leads to growing unemployment problems and slum settlements (United Nations Human Settlements Programme, 2003). For example, the two largest cities in the Pacific Islands, Suva in Fiji and Port Moresby in Papua New Guinea, have 
already grown to consist of over $45 \%$ "informal" (slum) settlements (United Nations Human Settlements Programme, 2010; Pabon et al., 2012).

Urban drift and loss of access to the seas brings a deep cultural loss. Neighbouring islands become increasingly disconnected, straining links between archipelagic and broader oceanic communities. Traditional cultures that lived on the sea as much as they did on the land are in decline. As youth move to cities or emigrate, aging and populations declining in size and health are left in their wake. One increasingly suggested option to reinvigorate traditional connections with the waterways and in turn, engender positive social and environmental transformation could be a rooted in a return to sail for maritime shipping.

\subsection{Conventional shipping and the environment}

Expansion of global trade is directly related to expansion in shipping, which currently accounts for $90 \%$ of global commerce (United Nations Environment Program (UNEP), 2012). The vast majority of this shipping occurs via large conventional vessels propelled by fossil fuels.

Continued expansion of the shipping sector directly impacts the environment through the release of greenhouse gasses (GHG), the pollution of waterways, and the destruction of seabeds and coral reefs. A fuel-propelled ship produces pollution at every stage of its lifecycle. The shipping sector was estimated to be responsible for at least 3.3\% of total GHG emissions in 2007 (Buhaug et al. 2009). While this percentage appears relatively small, if "international shipping" were categorized as a country, it would rank as the 6th largest GHG producer in the world (Harrould-Kolieb, 2008). Sixteen of the worst polluting cargo ships together emit more sulfur dioxide pollution than the entire world's cars combined (Pearce, 2008). The majority of shipping's GHG emissions originate from lowcost heavy fuel oil (HFO) consumption, which has been traditionally used to decrease operating costs. Nearly $95 \%$ of two-stroke engines and around 70\% of four-stroke engines used in small shipping use HFO (Corbett and Winebrake, 2008). The increasing amounts of carbon being absorbed by the oceans (Feely et al., 2004), along with other pollutants including the annual release by shipping of "9.2 $\mathrm{Tg}$ for $\mathrm{SO} 2,0.35 \mathrm{Tg}$ for primary $\mathrm{SO} 4$, and $16.4 \mathrm{Tg}(\mathrm{NO} 2)$ for NOX" (Hassellöv et al., 2013:2,732), is acidizing the seas and impacting marine food webs. The regular operation of a fuel-based ship is also responsible for dispersing a variety of other pollutants, including: oil, chemical, and liquefied gas spillage particulate matter and methane exhaust emissions, as well as noise pollution (Goldsworthy, 2010; UNEP, 2012).

Pollution occurring during transit is accompanied by localized contamination in ports (Corbett and Winebrake, 2008; International Maritime Organization, 2009). Furthermore, dredging or land reclamation is required to accommodate ever larger container ships, which can adversely impact marine environments (US Army Corps of Engineers, 1983; UK Marine Sacs Project, 1999). Release of sediments through dredging and disposal of dredged material physically disturbs the nesting and spawning of fish, destroys vital seabeds and other habitats, and degrades water quality (Jackson et al., 2001; Reine et al., 1998). Through stricter regulations and mitigation measures, the impact of dredging can be decreased, however in cases where dredging destroys seabeds, restoration methods have been mostly ineffective (Moberg and Rönnbäck, 2003).

Decommissioning a ship usually occurs at the end of its life cycle, typically after 20-25 years of usage. Around 700 ships are dismantled or scrapped annually (Reynolds, 2004; Tibbetts, 2001) releasing pollutants into the air and waterways that can be detrimental to workers, other inhabitants and the environment. When old ships are decommissioned and taken apart, primarily to recover steel, there are toxic components that must be disposed of, including asbestos, PCBs, and toxic metals such as mercury and lead. Toxic wastes, though accounting for though only around $5 \%$ of the total weight of an average ship, can be a significant source of hazards for workers and environmental pollution (Clapp, 2010). At present, ship breaking generally takes place in the scrap yards of developing countries such as India, China, Pakistan, Bangladesh, the Philippines, and Vietnam where the handling of toxic chemicals is less regulated and waste disposal is less expensive (Furtado, 2000; Puthucherril, 2010). The task of ship breaking shifting mainly to the developing world is an example of how externalities of challenging global environmental problems are foisted on the global South.

\subsection{Changing regulatory environment impacting conventional shipping}

The shipping sector has remained relatively unregulated until recently. Whereas the International Maritime Organization (IMO), a UN regulatory body, expanded its mandate on environmental concerns to include greenhouse gas emissions in 2008, a lack of incentives and enforcement mechanisms hinder its effectiveness (Wuisan et al., 2012). Eventually, in January 2013, the IMO adopted mandatory measures to reduce GHG emissions (IMO, 2013). The Energy Efficiency Design Index was introduced for new ships, where existing vessels were subjected to the Ship Energy Efficiency Management Plan.

Non-State actors, such as the Green Award Foundation established in 1994 and the Clean Cargo Working Group created in 2003 have been formed to monitor and provide incentives to the shipping industry to minimize its environmental impact (Green Award Foundation, 2009; 2014; Businesses for Social Responsibility, 2013). The Shipping Key Performance Indicator and Environmental Ship Index were also developed, in 2010 and 2011, 
respectively, to contribute to environmental impact reduction and more (SOFTImpact, 2010; World Ports Climate Initiative, 2013). SustainableEfficiency.org launched by the Carbon War Room (2013a) allows users to calculate and compare the energy efficiency of 60,000 existing ships. The Vessel Design Tool Package has also been developed to assess the lifetime environmental impact of ships from the time they are laid down to the time of their decommission (Ellingsen et al., 2002).

Whereas analysts like Buhaug et al. (2009) argue that implementing emission reduction measures are cost prohibitive, gains in efficiency could save the shipping industry US\$ 50 billion a year in fuel costs while reducing emissions by 220 million metric tons per year, according to the Carbon War Room (2013b). Since fuel is the most costly aspect of ship operation, as fuel costs rise, there is a greater incentive for operators to identify innovative ways to reduce relative consumption (UNEP, 2012).

Although ship operators that make efficiency improvements can gain long-term savings, the short-term costs could be extremely prohibitive, especially for those in developing nations. These States have been permitted a waiver until 2019 to meet the UN measures, since certain factors make meeting regulatory standards difficult. As time passes, more regulations and tax policies are being drafted. Furthermore, any country that flags a ship in a developed country can also receive a waiver. Another criticism lies in how the IMO standards do not directly address the source of emissions - the regulations only encourage the use of vessels that produce fewer emissions, not energy sources that produce fewer emissions. These regulations also fail to tackle the other environmental impacts created during the shipping process.

\section{Return to wind}

As fuel costs rise and environmental degradation increases, shippers are incentivized to explore the potential of alternative propulsion methods. Wind, with its former preeminence on the seas, appears best placed of these propulsion sources to be reincorporated into shipping.

Hydrocarbon-fuel-powered vessels dominate the scene, but it has not always been so - it was wind billowing in the sails that propelled most ships on the high seas. But wind has been so completely superseded by fuel power (for all but sport) that what is called to mind when sail is mentioned may well be the square-rigged European tall ships of the nineteenth century. Sailing ships like the famous tea clipper Cutty Sark or those that played roles in voyages of discovery (Endeavour) or that established colonial settler societies (Mayflower) remain iconic representatives of a past age. "In Britain, steam-powered ships became the preferred method of waterway transport, replacing wind-powered ships by the 1930s", which were themselves replaced by fuel powered ships, a process largely completed by the 1990s. (Grübler and Nakićenović, 1991:328, 330).

Shipping under sail has been a fundamental element of social and economic life in coastal and island societies throughout history (Couper, 2008; D'Arcy, 2008; Howe, 2006). Traditional knowledge was honed and expressed itself in vessels, such as the wind-powered 140-foot Drua ships of Fiji that sailed the seas in the late 1800s at 13-15 knots (Otago Daily Times, 15 March, 1864, Issue 699:6 cited in Nuttall 2013:224). Sail led to the establishment of trading routes from the South China Sea through India to the Mediterranean (Manguin, 1993) and beyond.

\subsection{Sail in the present era}

In the present era, sail invokes dichotomous images. On the one hand, there are the expensive, ultra-modern, high-tech yachts for sport or pleasure of the privileged. On the other, flimsy dinghies sailed by the poorest of fishers. In a world dominated by fossil fuel powered shipping, sail has been long relegated into these niches on the extreme margins. Whereas the status quo has sail largely consigned to peripheral roles, there are notable and novel cases where sail is being used commercially. Examples include the Kwai, a converted sail-assist Norwegian fishing vessel that sails between Rarotonga and Hawaii (Nuttall, 2013). The extent to which traditional and hybrid sail vessels are being utilized for transport and shipping in SIDS and developing countries is not fully understood. Motorized vessels remain dominant on regional and international shipping routes, but small-scale, wind-powered boats are still utilized for some functions locally in places including the Caribbean, East Africa and West Africa (Boerne, 1999).

\subsection{Cost imperatives leading to reconsideration of sail}

Modern commercial long-distance shipping, anticipating further rises in the prices of fossil fuels and increasingly stringent regulations to abate the externalities of fossil-fuel combustion, has shown an interest in developing sail power as a means of reducing the reliance on such fuels (Hobson et al., 2007; Rojon, 2013; Ariwa, 2014). Yet considering the present rate of technological development and adaptation (see Rojon, 2013), in the near future it remains highly unlikely that renewable energy technologies alone will be capable of fully replacing conventional fuel-based propulsion methods on large vessels. As such, it is combinations of fossil fuel and renewable energy propulsion that are proving the more attractive route for investigation for larger-scale shipping.

\subsection{Sail-assist}

Potential for reducing reliance on fuel propulsion for larger shipping comes in the form of sail-assist. The term as used here refers to hybrid propulsion concepts in which wind 
power is used as an auxiliary power source to alleviate use of the main fossil-fueled propulsion systems. A selection of sail-assist concepts for commercial ships over 30 meters in length is presently being considered; plans and configurations are being designed, modeled, prototyped, and tested for a variety of applications globally.

A Japanese merchant company and the Government of Fiji were among those experimenting with adding sail to ships (see Shin Aitoku Maru, Na Mataisau, and Cagidonu in Teeter, 2014) during the oil shocks of the 1970s and 1980s, resulting in fuel savings of up to $30 \%$. Additionally, these ships saw increased stability under harsh weather conditions and reduced engine wear, and back up sails were available if motors failed (Sailing for Sustainability, 2012). However, with the return of fuel prices to long-term trends, these projects were abandoned (Hobson et al., 2007).

In the 1980s, over 350 artisanal fishing vessels in the Pacific Islands were equipped with sails. Unfortunately, a lack of confidence about the functionality and economic viability of the ships led to limits to their use (Gulbrandsen 1987; Sailing for Sustainability, 2012).

Design concepts range from the retractable vertical wing concept for very large carriers (see Wind Challenger in Teeter 2014) to the flying, parasail-type towing kite available for retrofitting standard ships (see Skysails in Teeter 2014), as well as various custom-designed small- to medium-sized, commercial hybrid vessels (see Fairtransport and B9 in Teeter, 2014). In order to be commercially viable within the business plans that dominate contemporary transoceanic (long-distance and large-scale) shipping, projects for commercial wind-assist (and to a lesser extent, solar-electric-energy-assist) must by necessity be calibrated to fit into existing commercial niches.

Towing kites can be attached to the bow of a ship to provide a thrust force from the wind that would substitute for engine power (Faber et al. 2011). Hamburg-based SkySails (2011) reports fuel savings of 10-35\% from the installation of their towing kites.

In 2009, Enercon launched its new 123-meter rotor-ship, E-Ship 1, with modern Flettner rotors, a spinning vertical rotor that converts wind power into propulsive energy. Enercon (2013) reported fuel savings of up to $25 \%$ per 170,000 miles of voyage. US-based shipping technology firm Magnuss, Singapore-based Windagain, and UK-based environmental NGO Greenwave are also working on Flettner rotor based models (Rojon, 2013).

\subsection{Other propulsion sources}

Wind is not the only source of renewable power to which shipping companies are turning. Some companies are researching supplementing sail with solar energy. Australian-based Solar Sail has combined sail with solar, promising 20-40\% reductions in fuel (McLaren, 2008) whereas Eco Marine Power Co. Ltd., based in Japan, is retrofitting vessels with sail panels fitted with solar modules (Atkinson, 2011). Sauter Carbon Offset Design is designing ships that harness sun, wind, and tidal energy (Einemo, 2010).

Naturally, the operating costs and business plans of hybrid models (fossil fuel + wind) remain linked to variations in the cost of petroleum and other associated variables. Although these technologies have shown increases in fuel efficiency, their impact on the market has been insignificant due to cost barriers and slow technological diffusion (Rojon, 2013; Teeter, 2014). However, they have the potential to be implemented at a more appropriate and affordable scale than non-fuel shipping platforms that shall be discussed below.

\section{Appropriate technology as maritime infrastructure}

A potential answer to some of the aforementioned challenges presented by the inadequacies of conventional small shipping is the reintroduction of sail coupled with solar power (photovoltaic, or PV). At the scales needed to provide opportunities and resilience for more fragile economies and remote locations, this combination of technologies could be considered the most feasible and appropriate.

\subsection{Attempts at reintroducing sail and lessons learned}

Nuttall (2013) discusses several attempts to reintroduce alternative energy propulsion vessels in the context of the Pacific. Following the oil shocks of the 1970s until the present, several attempts have been made. Nuttall's study looked at the Na Mataisau and Cagidonu (Fiji), Shin Aitoku Maru and the Japanese experiments with oil tankers, a FAO artisanal fishing craft initiative in the Pacific, multi-hull crafts in Tuvalu and the Tai Kabara. He found that alternative shipping technology may bring benefits across a range of local community settings throughout coastal and island Oceania, provided conditions are met, scale in particular (Nuttall, 2013).

\subsection{Greenheart Project}

The Greenheart Project, a Tokyo-based international nonprofit organization, is in the process of building a prototype vessel based on its own open-source design (Greenheart Project, 2011). The Greenheart design uses tried and robust yacht-type sails and standard rooftop solar panels to create a commercial vessel (see Figure 1).

The design for the Greenheart class prototype vessel is an attempt to balance affordability with practical features for maximum functionality in marginalized economies. Thirtytwo meters in length and capable of transporting three shipping containers, it has been designed to function as a 


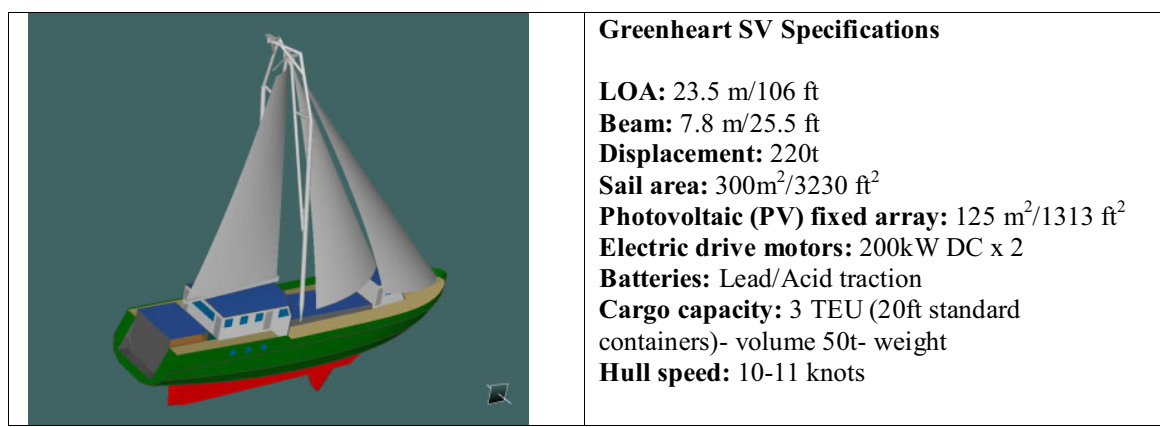

Figure 1. Greenheart SV specifications. Source: Greenheart Project Open Design Forum (2013).

sailing ship with Dacron (cloth) sails, and generate electricity via photovoltaic solar panels.

This solar power generation system remains engaged while docked or beached, with excess electricity stored in banks of lead/acid batteries. By using traditional sailing routes and modern techniques, in addition to a solarpowered auxiliary electric motor when required, the sailing vessel Greenheart will operate without any necessity for fuel products for either propulsion or electrics.

The characteristics of size, shallow draught and folding masts mean Greenheart vessels will be able to travel under bridges and up rivers, to access and load/ offload at undeveloped ports and locations presently unable to accommodate ocean-going vessels, thus providing new access to international markets for small producers. Furthermore, the ship has a crane/mast designed to double as a crane used to bring cargo on and off the vessel. The ship is designed to be free from the supply chain limitations for both parts and fuel, and the ship is serviced with readily available materials (Greenheart Project, 2011).

The key objective of the Greenheart Project is to produce a new, clean and appropriate technology platform and offer it to communities that can benefit most from its implementation. In the process of doing this, the organization seeks to increase the market share for environmentally sustainable transport and Fair Trade around the world, while contributing to research in the fields of clean technologies and sustainability.

Obstacles include engineering challenges, organizational complexity, and coordination with experts in several fields. Based on an open-source, non-profit model, it has received backing from several sponsors, for both equipment and financing, including WWF, Iridium, Upsolar, and Deltadesh, and is now seeking the necessary backing to carry it through the prototype construction phase.

The novel nature of the project presents both opportunities and challenges in terms of funding. The Greenheart strategy for funding the remainder of the project consists of continuing to secure grants and donations sufficient to build the first ship and operate it for a two-year period before achieving full financial independence. As a prototype vessel, the sailing vessel Greenheart is to be engaged in a wide variety of applications while testing the ship's capabilities under a broad range of conditions.

The initial operations scheduled for the prototype are based on an around-the-world voyage that includes cartage of goods for profitable resale, trialing sustainable commercial fishing operations, transporting development and relief supplies for partner organizations, and promoting various public education campaigns. Through consultations and experimentation on the maiden voyage (see Figure 2), the approximate parameters of the vessel's profitability in a variety of business models for developing and developed countries alike should be examined.

The design of the vessel has been chosen to facilitate the connection of the most remote coasts and rivers of the world with centers of the world's most prosperous cities. This philosophy extends to the crew, one third of which, during this maiden voyage, will be paid trainees from developing nations, learning the technical and administrative skills useful for launching similar sustainable enterprises in their home waters, with a view to building a fleet of nonpolluting sailing cargo ships for use in a range of social and commercial ventures (see Figure 3).

\section{Change and policy implications}

This section will discuss how the unique set of attributes of low-volume, clean energy ships, when used in sufficient numbers, could affect positive changes in the way both fishing and maritime transport enterprises are carried out in developing economies. Some potential policy initiatives to assist the adoption of such vessels will be proposed.

A distinctive feature of the design for Greenheart-class vessels is the ability to sail even the longest routes in spite of their relatively small size. This is a break from the present configuration of the world fleet, where economies of scale for fuel-driven vessels dictate high-volume for long routes (Grübler and Nakićenović, 1991). True for both fishing and cargo trades, fuel costs per mile demand a business model that makes distance a variable that favours large vessels and centralized (hub and spoke) networks in which ship operators pay the least possible operating costs 


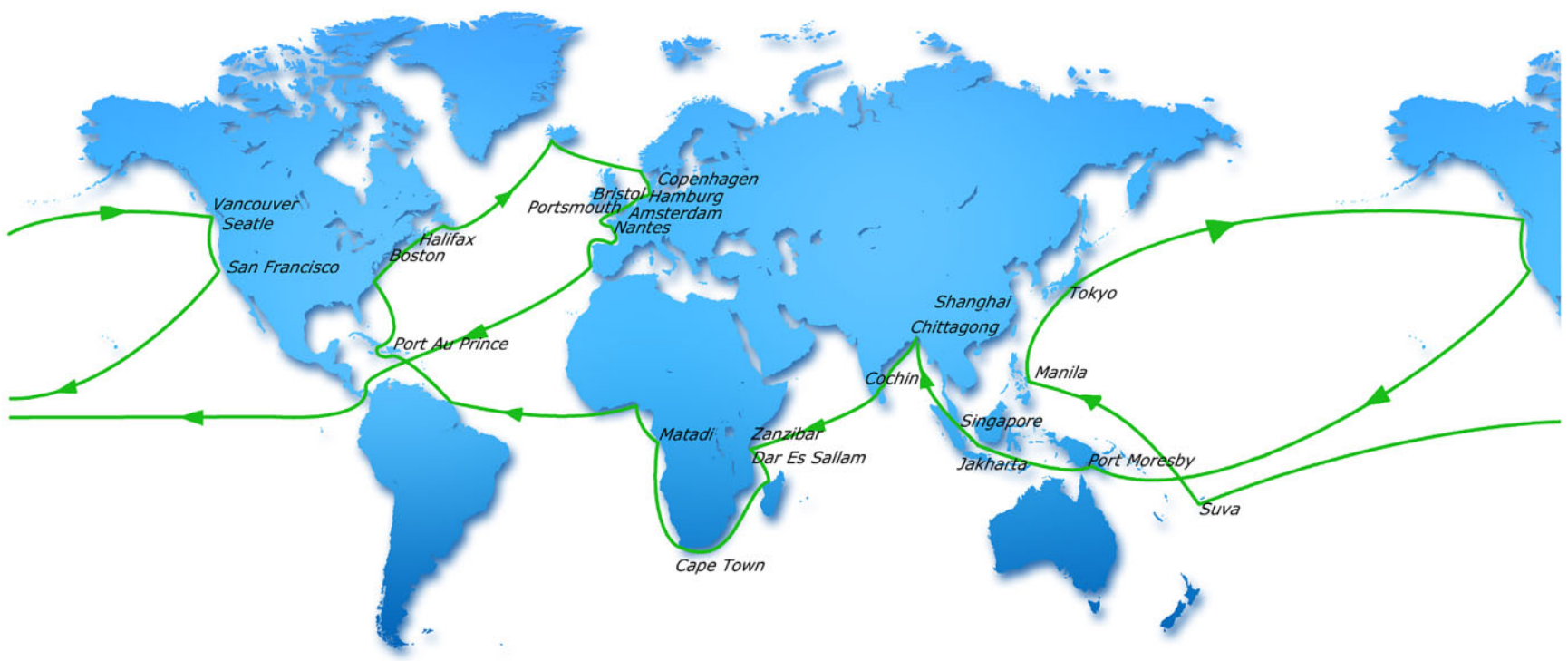

Figure 2. Route of maiden voyage.

Source: Obtained from the Greenheart Project (2011), open source.

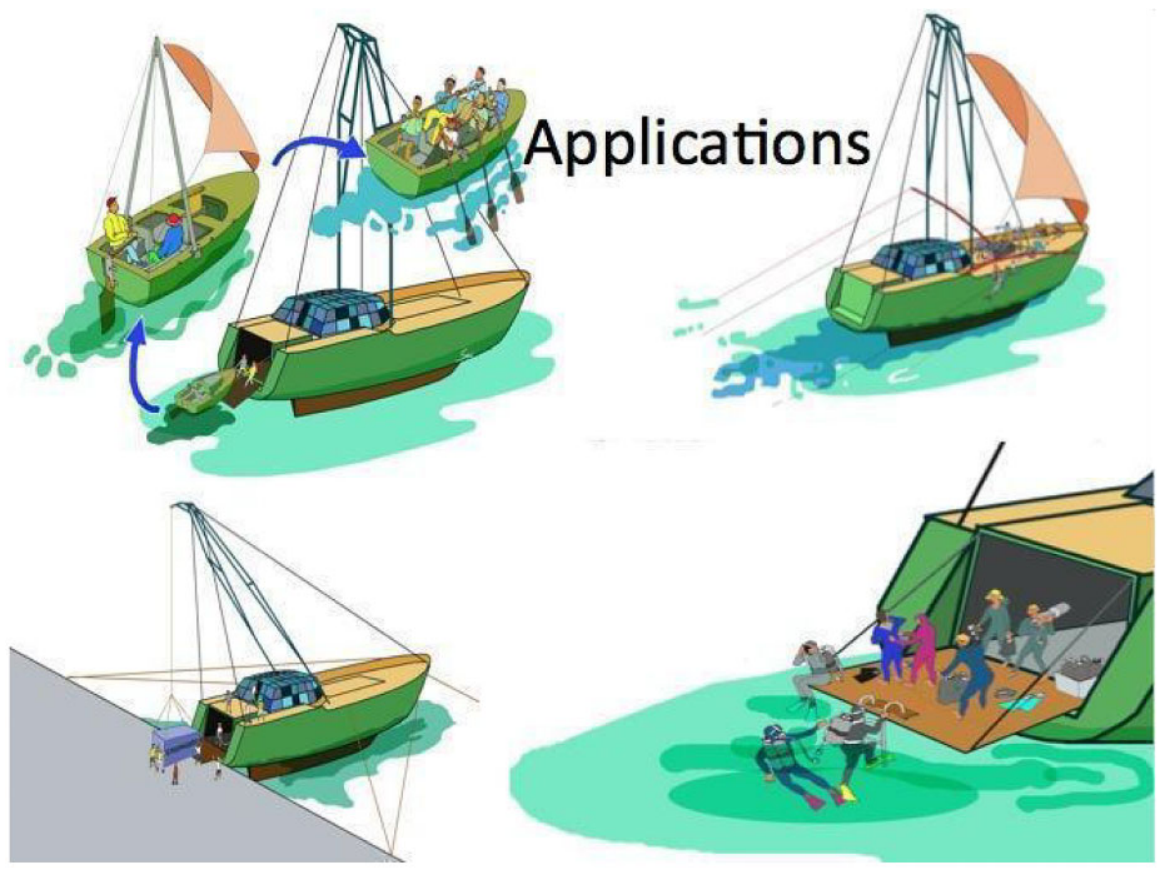

Figure 3. Versatility of the Greenheart sailing vessel.

Note: Potential applications include fishing, cargo transport, and tourism.

Source: Obtained from the Greenheart Project (2011), open source.

per metric ton/mile of cargo (or metric ton of fish). This factor forces a correlation between distance and volume that excludes, or adds costs to, remote and low volume shippers around the world. Sail-solar vessels are freed of the per-mile costs of fuel and lubricants, as well as the bunkering (refueling) scheduling and routing costs.

Another feature of the Greenheart design is shallow draft compared to an average ocean-going vessel. Much smaller than present craft, and especially designed to access shallow regions, Greenheart ships can directly connect people and their industries that now are inhibited by the higher costs of land transportation or field transport with multiple transfers to larger seaports. With Greenheart-class vessels, populations in such regions, which include the vast majority of the world's inhabited coastlines, will have greater access to distant fishing grounds, and with a connection to the 
containerized deep-water ports of the global trading network, the chance to trade directly with other underserviced coastlines around the world.

\subsection{Policy recommendations}

Dissemination and the adoption of sustainable marine platforms is expected to increase in response to incentives to minimise cost exposure to rising fossil fuel prices. However, there are regulatory and policy adjustments that could accelerate the process.

The Greenheart Project seeks to introduce an integrated approach to sustainable development, scalable to the regional level. The characteristics of the Greenheart ships enable and encourage social, environmental, technical and commercial innovations. The prospective for Greenheart class vessels to service a growing niche and contribute to systemic solutions exists, as the project spans sectoral boundaries (transportation, fishing, anti-urban drift, distributed and flexible transport and renewable energy production). The vessel's functional applications, low ecological impact and other desirable aspects, such as the fleet's open source tech support, make it a potential development tool for those proximate to navigable waters.

In comparison with conventional small shipping, Greenheart class vessels are intended to:

- be cheaper;

- be more versatile;

- provide greater economic and climate resilience;

- have a minimal ecological footprint;

- replace oil-dependent land and air infrastructure;

- increase petroleum fuel efficiencies in villages and populations outside of present supply chains; and

- generate electricity even when not in operation.

The physical features and operational capabilities of Greenheart ships permit novel utility and access to the global commons more equitably, and with leapfrog competitive advantages, such as:

- certifiable, value-added consumer labeling showing Fair Trade, low-carbon, and sustainable fishing credentials;

- improved routing flexibility, unconstrained by fuel supply chains;

- minimal operating costs: fuel-free, less maintenance, lower labour costs;

- less economic pressure to keep ships constantly in profitable operations, since each vessel is producing electrical energy every day; and

- the possibility for seasonal and opportunistic function changes: ships are easily convertible between, fishing, cargo, and other functions

Presuming that Greenheart-class, low-volume, longrange, multi-use ships could complement the work fleet in poorer nations, a set of policies to facilitate the adoption should be considered. A single ship could be a useful tool to any marginalized coastal village or struggling community along navigable riverbanks or lakeshores. However, the effect of a general transition to cleaner and more appropriately designed multi-use vessels around the world would also have a positive impact upon persistent global challenges: environmental, economic, and social. The availability and potential of this simple low-tech re-tooling, if made known to policymakers and regulatory actors around the world, would help to adjust rules and incentives accordingly, on a more sustainable path.

At present, many SIDS and developing countries have no practical access to long-range fisheries, much less the added profits of operating factory ships. In many cases, designated authorities cannot effectively patrol nor police the marine territories that they are entrusted to protect. A country's territorial waters, exclusive economic zones, and marine protected areas, are typically not respected in the absence of effective and continuous patrols and monitoring, yet the cost of operating patrol ships capable of continual presence in protected and exclusive areas is too great for many small and impoverished nations to bear (Mora and Sale, 2011). The absence of fuel constraints will allow extended trip lengths for non-fuel fishing and monitoring vessels, an option presently unavailable to poorly capitalized fleets around the world.

With the global industrial fishing capacity presently at $250 \%$ of what is recommended to maintain stocks sustainably (Porter, 1998) policies that move established and developing fishing industries towards correcting overcapacity by favouring smaller, cleaner vessels in the tax, fee and regulatory schemes at national and international levels are needed. The processing trawlers and motherships that international commercial operators now own and utilize burn between hundreds and thousands of metric tons of fuel on a single voyage. Of course these massive factory ships carry huge harvests, but in order to cover fuel bills, unsustainable yields of target fish (with attendant by-catch) must be achieved along the way. A fleet of thousands of fuel-free, low-volume ships could positively impact the sustainability of the current fishing industry.

Low-volume vessels mean more people employed per metric ton of food fish. This applies to the fishing crews themselves, and to the extensive supply chain and fleet maintenance industries. In addition, having multi-use vessels distributed around the world's coasts could enhance economic resilience, climate change adaptability and natural disaster preparedness. Safety is another factor improved by using smaller ships with lighter gear. The heavy industrialization of offshore fishing has rendered it one of the most dangerous industries for the men and women employed to catch and trap seafood.

Keeping oceans healthy and productive into the future is a key element in weathering the expected 3 billion person 
increase in world population (United Nations, 2004). Tools and practices for doing this must be promoted and incentivized by responsible Governments and agencies immediately.

Not only fishing industries, but also cargo transport fleets of the world, could benefit from a sub-fleet of low-cost, zero-fuel, low-volume carriers. Unlike fishing fleets' oversaturation with high-volume ships, the cargo transport sector has improved its efficiencies by using large and ultralarge cargo ships between deepwater ports around the world. Costs per container, or per metric ton of bulk commodity, between these cargo hubs is low and facilitates vigorous international trade. Although maximizing efficiency at the hubs, these systems become less costeffective as goods are transferred to smaller carriers, or on to trucks and road networks to connect to end-users. The cost of moving a small amount of product to or from the developing world is often a major factor hindering development.

A welcome complement to the network of large cargo ships plying high-volume routes would be a myriad of small, cheap, fuel-free ships, that are not solely reliant on established port facilities but have the range and capability to connect any two coastal or riverine points; this would be an obvious advantage. Such a "distributed transport" network also promises to distribute the opportunity for developing regions to access the economic efficiencies of globalization while setting them on a low-carbon development path. The cultural component of free and selfdetermined access to the entirety of the world's shores is the crowning element among the benefits of long-range sustainable transport. Exposure and connection to the rest of the world has proven a sort of positive feedback loop in the evolution of entrepreneurialism. This connection and a sense of empowerment and pride in being the exemplar of best practices everywhere should prove remedial to some societal problems (see Pacific Voyagers Society in Teeter, 2014).

When creating policy designed to facilitate the spread of decentralized transport infrastructure and sustainablyscaled fishing fleets, care must be taken to allow for the radical shift into the new and desired arrangement. Ship ownership has long been the domain of the State, wealthy individuals and corporations so the optimal legal and regulatory configuration for such a paradigm shift to family, village, and cooperative ownership has not yet been established. We recommend that early adopters be consulted carefully to help establish new protocols. The authors suggest the following policy adjustments be readied to facilitate the dissemination of the new low-volume, green sector of the world fleet to the maximum efficient size as quickly as possible:

- Customs and clearance inspections: Decentralize customs clearance and inspections, and fisheries inspections protocols, so they can be fulfilled in smaller villages, facilitating less centralized, distributed, sustainable, small ports, and improving efficiencies by removing the need for travel time to and from existing administrative centers. A simple "deputization" scheme is one with potential to empower local authorities to assume duties locally.

- Improve infrastructure: Replace coastal overland infrastructure plans for the expansion and improvement of transportation networks with Greenheart-class shipping light-footprint port networks. Low investment thresholds would seek to render Greenheart-class shipping infrastructure networks more resilient and cost-effective than current road, air, or deepwater port transport networks.

- Procedural improvements: Streamline licensing, certification and port clearance procedures to reduce bureaucratic burdens on maritime entrepreneurs.

- Investment in traditional knowledge: Invest in conserving and recording traditional knowledge and expertise in the subjects of local piloting, weather prediction, and sailing lore. Recognize these skills and expertise in the accreditation process for ship's officers and crew, where applicable.

- Flexibility in permitting: In order to facilitate the multiuse application model for Greenheart ships, accommodate this novel business concept with multi/ flex-use permitting regulations, business licensing, and tax scheduling.

\section{Conclusions}

Conventional shipping for transport and fishing, with an inherent bias towards high volumes, deep, highly-developed ports and fossil fuel-dependence, have further marginalized already vulnerable communities. It is proposed that the introduction of ships that are not inhibited by range or costs of fuel could provide a potential solution to connect these communities to each other and the greater global trading system.

Meanwhile, the design innovations of vessels of the Greenheart class is projected to permit access to places that have become increasingly dependent on land transport for the provision of goods and services. The greater number and extent of viable routes and lower costs could allow SIDS and other coastal communities in developing countries to facilitate greater trade on local, regional and global scales.

Many potential positive outcomes are expected to result from changes in policy that can allow for sail-solar shipping to diffuse to populations that seek to adopt them. Benefits are expected to flow from reforms that facilitate customs and clearance inspections, infrastructure and procedural improvements, investment in traditional knowledge, and more flexible systems for granting permission for operations. 


\section{References}

Al Jazeera, 2013. Fiji fights to stay afloat as fuel costs soar, April 8, Available at http://www.aljazeera.com/news/asia-pacific/2013/04/ 2013485134121317.html (accessed 10 June 2013).

Atkinson, G., 2011. Eco marine power continues development of Aquarius Solar and Wind Power System for ships. Available at http://www.ecomarinepower.com/images/stories/documents/aquarius _\%2020media_release_20110222a.pdf (accessed 20 June 2013).

Ariwa, E., 2014. Green Technology Applications for Enterprise and Academic Innovation. Hershey, PA: IGI Global.

Boerne, G.L., 1999. Filling the Gap: Small Inter-island Caribbean Trading Ships and their Crews. Cardiff: Seafarers International Research Centre.

Buhaug, Ø., Corbett, J.J., Eyring, V., Endresen, Ø., 2009. Second IMO GHG study. London, UK. Available at http://www.imo.org/blast/ blastDataHelper.asp?data_id=27795 (accessed 15 December 2013).

Businesses for Social Responsibility, 2013. Clean cargo. Available at http://www.bsr.org/consulting/working-groups/BSR_Clean_Cargo _Working_Group.pdf (accessed 23 June 2013).

Carbon War Room, 2013a. ShippingEfficiency.org, Available at http:// shippingefficiency.org/about-us/shipping-efficiency (accessed 15 June 2013).

Carbon War Room, 2013b. Why invest in efficiency, Available at http://shippingefficiency.org/improve-your-efficiency/why-invest-in -efficiency (accessed 15 June 2013).

Clapp, J., 2010. Toxic exports: the transfer of hazardous wastes from rich to poor countries. Ithaca, NY: Cornell University Press.

Corbett, J.J., Winebrake, J., 2008. The impacts of globalisation on international maritime transport activity: past trends and future perspectives. Paper presented at the Global Forum on Transport and Environment in a Globalising World, Guadalajara, Mexico.

Couper, A., 2008. Sailors and Traders: A Maritime History of the Pacific People. Honolulu, HI: University of Hawai'i Press.

Crossley, M., Sprague, T., 2014. Education for sustainable development: implications for small island developing states (SIDS), International Journal of Educational Development 35(1): 86-95.

D'Arcy, P., 2008. The People of the Sea: Environment, Identity and History in Oceania. Honolulu, HI: University of Hawai'i Press.

Einemo, U., 2010. Black Magic pointing to green future for tankers. Bunker World 19 June 2010. Available at http://www.bunkerworld.com/ news/i94560/i-Black-Magic-i-pointing-to-green-future-for-tankers (accessed 5 December 2013].

Ellingsen, H., Fet, A.M., Aanondsen, S., 2002. Tool for environmental efficient ship design. Trondheim: Norwegian University of Science and Technology, Available at http://www.iot.ntnu.no/users/fet/ publi-forfatterskap/publikasjoner/ensus-ellingsen-fet-2002.pdf (accessed 22 June 2013).

Enercon, 2013. Rotor sail ship E-Ship 1 saves up to $25 \%$ fuel, Available at http://www.enercon.de/en-en/2224.htm (accessed 26 April 2014).

Faber, J., Wang, H., Nelissen, D., Russell, B., St Amand, D., 2011. Marginal abatement costs and cost effectiveness of energyefficiency measures. London: Institute of Marine Engineering, Science, and Technology. Available at http://www.imarest.org/Portals/ 2010/IMarEST/Community/IMO/MEPC2062\%2020INF \%2207\%2020Report.pdf (accessed 15 June 2013).

Feely, R.A., Sabine, C.L., Lee, K., Berelson, W., Kleypas, J., Fabry, V.J., Millero, F.J., 2004. Impact of anthropogenic $\mathrm{CO} 2$ on the $\mathrm{CaCO} 3$ system in the oceans. Science 305(5682): 362-366.

Fox, S., 2012. Urbanization as a global historical process: theory and evidence from sub-Saharan Africa, Population and Development Review 38(2): 285-310.

Furtado, M., 2000. Shipbreaking: a global environmental, health and labour challenge, Sao Paulo: Greenpeace, Available at http://www .shipbreakingplatform.org/shipbrea_wp2011/wp-content/uploads/ 2013/2003/2000-Greenpeace-report-to-IMO-MEPC-2044-session.pdf (accessed 22 June 2013).
Goldsworthy, L., 2010. Exhaust emissions from ship enginessignificance, regulations, control technologies. Australian and New Zealand Maritime Law Journal 24(1): 21-30.

Green Award Foundation, 2009. Green Award Homepage. Available at http://www.greenaward.org/ (accessed 1 December 2013).

Green Award Foundation, 2014. Foundation, Available at http://www .greenaward.org/26-foundation.html (accessed 23 February 2014).

Greenheart Project Open Design Forum, 2013. Mindtouch. Available at http://odf.greenheartproject.org/ (accessed 1 December 2013).

Greenheart Project, 2011. The vessel, Available at http://greenheartproject .org/new/en/vessel_des.html (accessed 10 June 2013).

Grübler, A., Nakićenović, N., 1991. Long waves, technology diffusion, and substitution. Review (Fernand Braudel Center) 14(2), 313-343.

Gulbrandsen, Ø., 1987. Artisanal Fishing Craft of the Pacific Islands. Suva: Food and Agriculture Organization of the United Nations.

Harrould-Kolieb, E., 2008. Shipping impacts on climate: a source with solutions, Washington, DC.: Oceana, Available at http://oceana.org/ sites/default/files/o/fileadmin/oceana/uploads/Climate_Change/ Oceana_Shipping_Report.pdf (accessed 20 November 2013).

Hassellöv, I.-M, Turner, D.R., Lauer, A., Corbett, J.J., 2013. Shipping contributes to ocean acidification. Geophysical Research Letters 40.

Hobson, M., Pell, E., Surgand, M., Kollamthodi, S., Moloney, S., Mesbahi, E., Wright, P., Cebezas Basurko, O., Pazouki, K., 2007. Low Carbon Transport. Oxfordshire: AEA energy and environment.

Holland, E., Nuttall, P., Newell, A., Prasad, B., Veitayaki, J. Bola, A., Kaitu'u, J., 2014. Connecting the dots: policy connections between Pacific Island shipping and global carbon dioxide and pollutant emission reduction, Carbon Management 5(1): 93-105.

Howe, K.R., ed. 2006. Vaka Moana Voyages of the Ancestors the Discovery and Settlement of the Pacific, Auckland: David Bateman.

International Maritime Organization (IMO), 2009. Revised MARPOL Annex VI: regulations for the prevention of air pollution from ships. London: IMO.

International Maritime Organization (IMO), 2013. Greenhouse gas emissions, Available at http://www.imo.org/OurWork/Environment/ PollutionPrevention/AirPollution/Pages/GHG-Emissions.aspx (accessed 15 June 2013).

Jackson, E.L., Rowden, A.A., Attrill, M.J., Bossey, S.J., Jones, M.B., 2001. Oceanography and marine biology an annual review. In: Gibson, R.N., Barnes, M. (Eds.), Oceanography and Marine Biology: an Annual Review. Volume 39. London: Taylor and Francis. pp. 269303

Manguin, P.-Y., 1993. Trading ships of the South China Sea. Shipbuilding techniques and their role in the history of the development of Asian trade networks. Journal of the Economic and Social History of the Orient 36(3): 253-280.

McLaren, W., 2008. Solar sailor sun sails to be fitted to Chinese cargo ships. Treehugger, Available at http://www.treehugger.com/solar -technology/solar-sailor-sun-sails-to-be-fitted-to-chinese-cargo-ships .html (accessed 15 June 2013).

Moberg, F., Rönnbäck, P., 2003. Ecosystem services of the tropical seascape: Interactions, substitutions and restoration. Ocean and Coastal Management 46(1-2), 27-46.

Mora, C., Sale, P., 2011. Ongoing global biodiversity loss and the need to move beyond protected areas: a review of the technical and practical shortcomings of protected areas on land and sea, Marine Ecology Progress Series 434(9): 251-266.

Nuttall P., 2012. Steering a course for the future with sticks, stones, grass and a little sharkskin: the case for revitalisation of sail technology and sailing culture as a practical sea transport response to climate change and fossil fuel dependence/supply issues in Fiji, Journal of Pacific Studies 32(special issue): 163-175.

Nuttall, P., 2013. Sailing for sustainability: the potential of sail technology as an adaptation tool for Oceana. A voyage of inquiry and interrogation through the lens of a Fijian case study (thesis), Victoria University of Wellington. 
Nuttall, P., Newell, A., Prasad, B., Veitayaki, J., Holland, E., 2013. A review of sustainable sea-transport for Oceania: providing context for renewable energy shipping for the Pacific, Journal of Marine Policy 43: 283-287.

Pabon, L., Umapathi, N., Waqavonovono, E., 2012. How geographically concentrated is poverty in Fiji?, Asia Pacific Viewpoint 53(2): 205-217.

Pearce, F., 2008. Confessions of an Eco-sinner. Boston, MA: Beacon Press.

Porter, G., 1998. Estimating Overcapacity in the Global Fishing Fleet, Washington, DC: World Wildlife Fund.

Prasad, B., Veitayaki, J., Holland, E., Nuttall, P., Newell, A., Bola, A., Kaitu'u, J., 2013. Sustainable sea transport research programme: toward a research-based programme of investigation for Oceania. Journal of Pacific Studies 33(1): 78-95.

Puthucherril, T.G., 2010. From shipbreaking to sustainable ship recycling evolution of a legal regime. Available at http://public.eblib.com/ EBLPublic/PublicView.do?ptiID=583761 (accessed 20 December 2013).

Reine, K.J., Dickerson, D.D., Clarke, D.G., 1998. Environmental windows associated with dredging operations. Vicksburg, MS: US Army Engineer Research and Development Center. Available at http:// el.erdc.usace.army.mil/dots/doer/pdf/doere2012.pdf (accessed 1 June 2013).

Reynolds, G., 2004. Sources, environmental impact and global contribution. In: Pinder, D., Slack, B. (Eds.), Shipping and Ports in the Twenty-first Century: Globalization, Technological Change and the Environment. London: Routledge. pp. 233-256.

Rojon, I., 2013. Blowin' in the wind? Possibilities of the International Maritime Organization to promote the uptake of wind propulsion in international shipping (thesis). Utrecht University, Nieuwegein.

Russell, L., 2009. Poverty, climate change and health in Pacific island countries: issues to consider in discussion, debate and policy development. Sydney: Menzies Centre for Health Policy, Available at http://ussc.edu.au/s/media/docs/publications/0904_pacificislandspaper russell.pdf (accessed 1 December 2013).

Rutz, W.O.A., Coull, J.R., 1996. Inter-island passenger shipping in Indonesia: Development of the system. Present characteristics and future requirements. Journal of Transport Geography 4(4): 275-286.

Sailing for Sustainability, 2012. Sailing for sustainability — overview. Available at http://www.sailingforsustainability.org (accessed 1 December 2013).

SkySails, 2011. DSM invests in wind propulsion company SkySails, Available at http://www.skysails.info/fileadmin/user_upload/ Presselounge/Dokumente/englisch/2004-E-2011-DSM_invests_in _wind_propulsion_company_SkySails.pdf (accessed 23 June 2013).

SOFTImpact, 2010. The shipping KPI system V2.0, Available at https:// www.shipping-kpi.org/book/page/1 (accessed 1 June 2014).

Teeter, J.L., 2014. Sustainable shipping to meet the needs of small island developing states. In Ariwa, E. (Ed.), Green Technology Applications for Enterprise and Academic Innovation, Hershey, PA: IGI Global.
Tibbetts, J., 2001. Hazardous waste. Constructing rules for dismantling ships. Environmental Health Perspectives Environmental Health Perspectives 109(11): 1091-1191.

US Army Corps of Engineers, 1983. Dredging and Dredged Material Disposal. Washington, DC: US Army Corps of Engineers.

UK Marine Sacs Project, 1999. Good Practice Guidelines for Ports and Harbours Operating within or near UK European Marine Sites. New York: UK Marine SACS Project.

United Nations, 2004. World population to 2300. New York: United Nations Available at http://www.un.org/esa/population/publications/ longrange2/WorldPop2300final.pdf (accessed 11 November 2013).

United Nations, 2010. Five-year review of the Mauritius strategy for the further implementation of the programme of action for the sustainable development of small island developing states. Geneva: UNCTAD. Available at http://www.sidsnet.org/msi_5/docs/. . ./A-65-115-English .pdf (accessed 5 September 2013).

United Nations, 2014a. International year of Small Island Developing States, Available at http://www.un.org/en/events/islands2014/ \#andpanel1-1 (accessed 1 April 2014).

United Nations, 2014b. Did you know? Available at http://www.un.org/en/ events/islands2014/didyouknow.shtml (accessed 1 April 2014).

United Nations Conference on Trade and Development (UNCTAD), 2013. Linear shipping connectivity index. Geneva: UNCTAD. Available at http://unctadstat.unctad.org/TableViewer/tableView.aspx?ReportId=92 (accessed 13 June 2013).

United Nations Environment Programme (UNEP), 2012. Green Economy in a Blue World. Nairobi, Kenya: United Nations Environment Programme.

United Nations Human Settlements Programme, 2003. Slums of the world: the face of urban poverty in the new millennium? Working Paper. Nairobi: UN-HABITAT.

United Nations Human Settlements Programme, 2010. Port Moresby Urban Profile. Nairobi: UN-HABITAT.

Woodruff, A., 2007. The potential for renewable energy to promote sustainable development in pacific island countries, SOPAC Miscellaneous Report, 692 Suva: SOPAC Available at www.theprif .org/sites/theprif.org/files/Potential for renewable energy — SOPAC renewable energy report 2007.pdf (accessed 28 April 2014).

World Bank, 2004. Effects of population growth and urbanization in the Pacific Islands. Available at http://siteresources.worldbank .org/INTPACIFICISLANDS/Resources/Chapter+1.pdf (accessed 30 December 2013).

World Ports Climate Initiative, 2013. Environmental ship index, Available at http://esi.wpci.nl/Public/Home (accessed 10 June 2013).

Wuisan, L., van Leeuwen, J., van Koppen, C.S.A., 2012. Greening international shipping through private governance: A case study of the Clean Shipping Project. Marine Policy 36(1): 165-173.

Young, J., 1993. Sailing to Levuka: the cultural significance of the island schooners in the late 19th century, The Journal of Pacific History 28(1): $36-52$. 